\title{
Sorption of Sulfadiazine, Norfloxacin, Metronidazole, and Tetracycline by Granular Activated Carbon: Kinetics, Mechanisms, and Isotherms
}

\author{
Pingping Liu • Qiaorui Wang • Chunli Zheng • Chi He
}

Received: 3 November 2016 / Accepted: 27 February 2017 /Published online: 9 March 2017

(C) Springer International Publishing Switzerland 2017

\begin{abstract}
Activated carbon has widespread application in antibiotic-loaded wastewater treatment in recent years, owing to its developed pore structure, high superficies reactivity, and excellent mechanical and chemical stability. In this work, sorption experiments of four representative antibiotics, including sulfadiazine (SDZ), norfloxacin (NOR), metronidazole (MDE), and tetracycline (TC), over granular activated carbon (GAC), which was made from maize straw, were firstly studied. Kinetics, mechanism, and isotherm models related to the sorption process were employed. Results revealed that the sorption capacity by GAC followed the order SDZ > NOR > MDE $>$ TC. The sorption kinetics of the four antibiotics well conformed to the pseudo-second-order model. Both the Weber-Morris intraparticle diffusion and Boyd kinetic models conveyed the information that film diffusion was dominant in the sorption process. The sorption isotherm was better fitted to the Langmuir model. This research may pave a basic way for removing antibiotics in municipal and industrial wastewater by activated carbon.
\end{abstract}

$\underline{\text { Pingping Liu and Qiaorui Wang contributed equally to this work. }}$

P. Liu $\cdot$ Q. Wang $\cdot$ C. Zheng $\cdot$ C. He

Department of Environmental Science and Engineering, Xi'an Jiaotong University, Xi'an 710049, People's Republic of China

C. He $(\bowtie)$

Department of Environmental Nano-materials, Research Center for Eco-Environmental Sciences, Chinese Academy of Sciences, Beijing 100085, People's Republic of China e-mail: chi_he@xjtu.edu.cn
Keywords Antibiotics · Adsorption · Kinetics · Nanotechnology $\cdot$ Isotherms $\cdot$ Remediation

\section{Introduction}

Antibiotics are widely used in humans and veterinary, and China is the largest producer and user of antibiotics in the world based on market sales data (Zhang et al. 2015). The total antibiotic usage in China in 2013 was estimated to be approximately $162,000 \mathrm{t}$, in which sulfonamides, tetracyclines, fluoroquinolones, macrolides, $\beta$-lactams, and others shared $5,7,17,26,21$, and $24 \%$ of the total usage, respectively (Zhang et al. 2015). The wide usage of antibiotics has led to their occurrence in different environmental compartments, such as wastewater treatment plants (Zhou et al. 2013; Watkinson et al. 2007), livestock farms (Watanabe et al. 2010; Zhu et al. 2013a, b), river water (Luo et al. 2011), sediment (Luo et al. 2011; Golet et al. 2002), soils (Chen et al. 2011; Chee-Sanford et al. 2009), and groundwater (Hu et al. 2010). Antibiotics have different half-lives in the environment. Some are highly persistent (Daughton and Ternes 1999), and therefore their contamination levels in the environment have been increasing (Ahmed et al. 2015). These compounds are potentially adverse to water quality and aquatic organisms (Carstens et al. 2013). Meanwhile, antibiotic residuals in the environment have access to the human body via the food chain and drinking water, resulting in antibiotic resistance and interference with the functioning of natural hormones ( $\mathrm{He}$ et al. 2016). Therefore, it is indispensable and urgent to effectively remove the antibiotics from impure water. 
<smiles>Nc1ccc(C(=O)Nc2ncccn2)cc1</smiles><smiles>CCn1cc(C(=O)O)c(=O)c2cc(F)c(N3CCNCC3)cc21</smiles>

NOR

SDZ
Molecular formula: $\mathrm{C}_{10} \mathrm{H}_{10} \mathrm{~N}_{4} \mathrm{O}_{2} \mathrm{~S}$

Molar mass: $250.277 \mathrm{~g} / \mathrm{mol}$

$\mathrm{P}_{\mathrm{ka} 1}: 1.57$

$\mathrm{p}_{\mathrm{ka} 2}: 6.50$

$\log \mathrm{K}_{\text {ow }}:-0.08930$

Solubility: $77 \mathrm{mg} / \mathrm{L}$

Molecular formula: $\mathrm{C}_{16} \mathrm{H}_{18} \mathrm{FN}_{3} \mathrm{O}_{3}$ Molar mass: $319.331 \mathrm{~g} / \mathrm{mol}$

$\mathrm{P}_{\mathrm{ka1}}: 6.30$

$\mathrm{p}_{\mathrm{ka} 2}: 8.38$

$\log \mathrm{K}_{\mathrm{ow}}:-1.030$

Solubility: $350 \mathrm{mg} / \mathrm{L}$

Fig. 1 Structure and physicochemical properties of the four antibiotics

Conventional treatment methods, mainly based on the use of microbes, cannot fully decompose antibiotics (Ahmed and Theydan 2013a, b). Thus, other technological alternatives, such as oxidation (Yahiaoui et al. 2013), ozonation and biodegradation (Gómez-Pacheco et al. 2011), and photocatalytic degradation (Zhu et al. 2013a, b), were suggested. Especially, the process of sorption has recently captured people's attention by having the advantages of easy operation, high reliability, design flexibility, and regenerability (Dabrowski 2001). Different kinds of sorbents, for instance, clinoptilolite (Lam et al. 2001), soil (Rabolle and Spliid 2000), several forms of activated carbons (ACs; Ahmed and Theydan 2013a, b; Çaliskan and Goktürk 2010; Rivera-Utrilla et al. 2009; Ocampo-Pérez et al. 2013), calcium phosphate materials (Queiroz et al. 2005), and core-shell magnetic nanoparticles (Chen et al. 2013), were utilized and their sorption performance was investigated.

Among these sorption materials, ACs have been reported as an effective sorbent to eliminate micro-pollutants because of their excellent porosity, huge specific surface area, low cost, and environmental friendliness (He et al. 2016). Kim et al. (2010) and Méndez-Díaz et al. (2010) reported that approximately $90 \%$ of trimethoprim and nitroimidazoles were removed from aqueous solution when activated carbons were used as the sorbent, respectively. Over $90 \%$ removal efficiency for sulphonamides (Adams et al. 2002), tetracyclines (Pouretedal and Sadegh 2014), and fluoroquinolones (Ahmed and Theydan 2014) was achieved by using activated carbons. These results demonstrate that activated carbons have promising use for<smiles>Cc1ncc([N+](=O)[O-])n1CCO</smiles>

MDE
Molecular formula: $\mathrm{C}_{6} \mathrm{H}_{9} \mathrm{~N}_{3} \mathrm{O}_{3}$ Molar mass: $171.15 \mathrm{~g} / \mathrm{mol}$

$\mathrm{P}_{\mathrm{ka} 1}: 2.58$

$\mathrm{p}_{\mathrm{ka} 2}: 14.44$

logKow: -1.909

Solubility: $7017 \mathrm{mg} / \mathrm{L}$

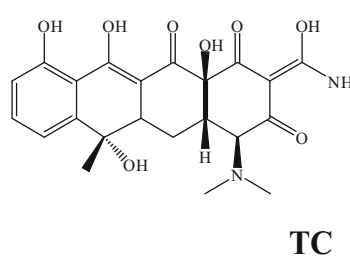

Molecular formula: $\mathrm{C}_{22} \mathrm{H}_{24} \mathrm{~N}_{2} \mathrm{O}_{8}$ Molar mass: $444.43 \mathrm{~g} / \mathrm{mol}$

$\mathrm{P}_{\mathrm{kal}}: 3.30$

$\mathrm{p}_{\mathrm{ka} 2}: 7.68$

$\mathrm{P}_{\mathrm{ka} 3}: 9.69$

$\log \mathrm{K}_{\text {ow }}:-1.19$

Solubility: $1700 \mathrm{mg} / \mathrm{L}$

TC the treatment of antibiotic-loaded aqueous solutions. Recently, it has been much inclined to prepare activated carbons based on agriculture wastes for antibiotic decontamination of wastewater. For instance, Ahmed and Theydan (2013a, b) obtained activated carbon based on Siris seed pods possessing large specific surface areas $\left(1676.6 \mathrm{~m}^{2} / \mathrm{g}\right)$ and high Langmuir maximum uptake of metronidazole (180.79 mg/g). Sayğılı and Güzel (2016) used tomato (Lycopersicon esculentum Mill) to prepare activated carbons. The specific surface area of this sorbent and the Langmuir maximum sorption capacity for tetracycline were $1093 \mathrm{~m}^{2} / \mathrm{g}$ and $416.7 \mathrm{mg} / \mathrm{g}$, respectively. Martins et al. (2015) removed tetracycline by $\mathrm{NaOH}-$ activated carbon produced from macadamia nut shells

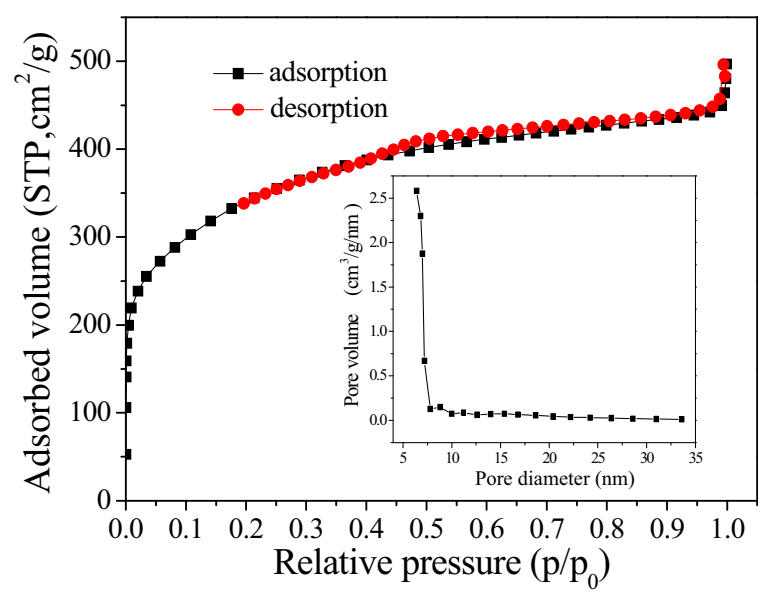

Fig. 2 Nitrogen sorption isotherm and pore size distribution of GAC 

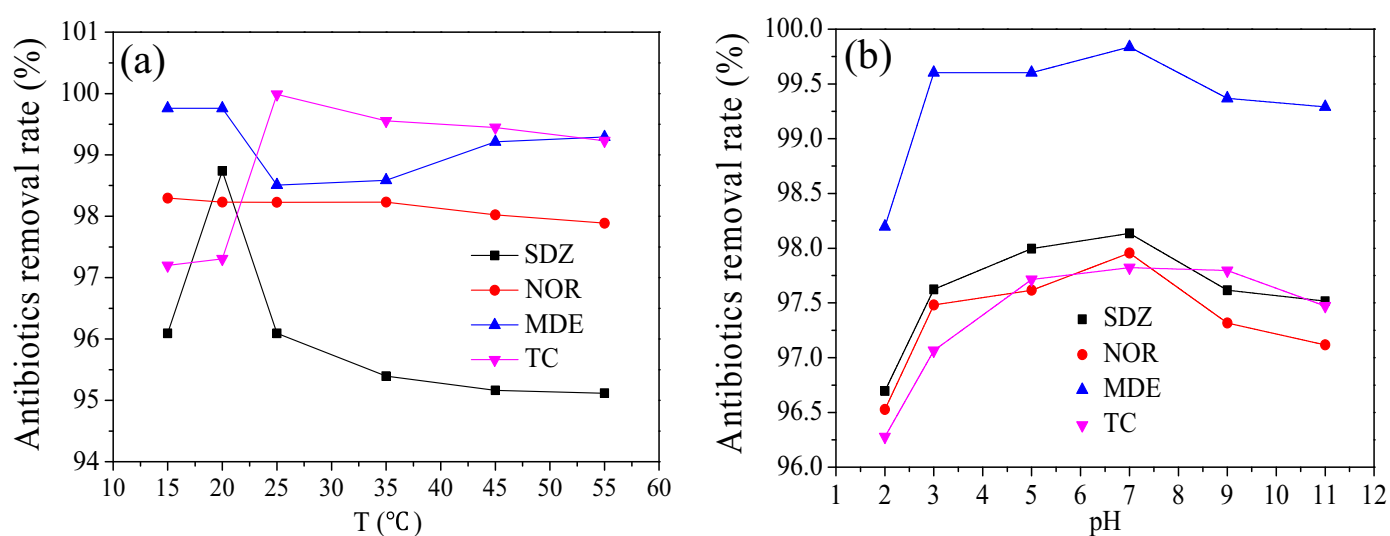

Fig. 3 Effects of temperature (a) and $\mathrm{pH}$ (b) on the sorption of antibiotics $\left(C_{0}=25 \mathrm{mg} / \mathrm{L}\right)$ by GAC

(the specific surface area of the activated carbon was $1524 \mathrm{~m}^{2} / \mathrm{g}$ and the maximum monolayer sorption capacity was $455.33 \mathrm{mg} / \mathrm{g}$ ). It can be also concluded that these agriculture waste-based activated carbons possess large specific surface areas and abundant pore structures; that is, they have great potential in the removal of antibiotics from aqueous solutions. However, to the best of our knowledge, there are few researches focusing on antibiotic
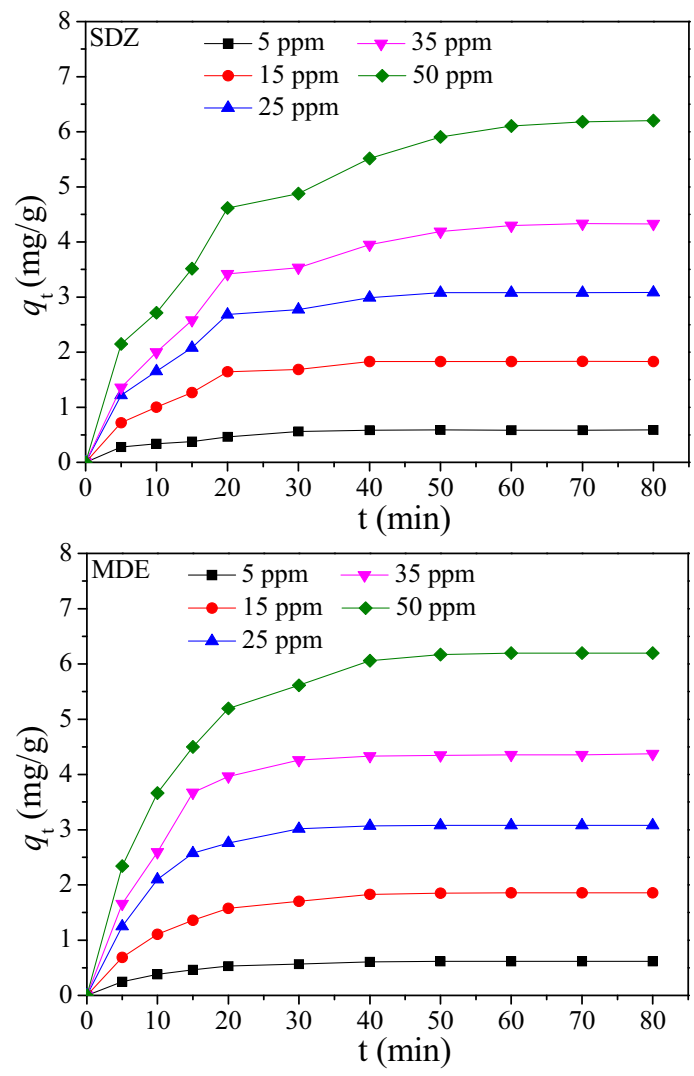

Fig. 4 Effect of contact time on the sorption of antibiotics by GAC removal by using maize straw-based activated carbons. In order to know well the advantages for antibiotic removal and the potential application of this sorbent, we investigated the characteristics of the sorption of four antibiotics to this kind of activated carbon.

In this work, granular activated carbon (GAC) based on maize straw was employed for all batch sorption. Four representative antibiotics, including sulfadiazine (SDZ),
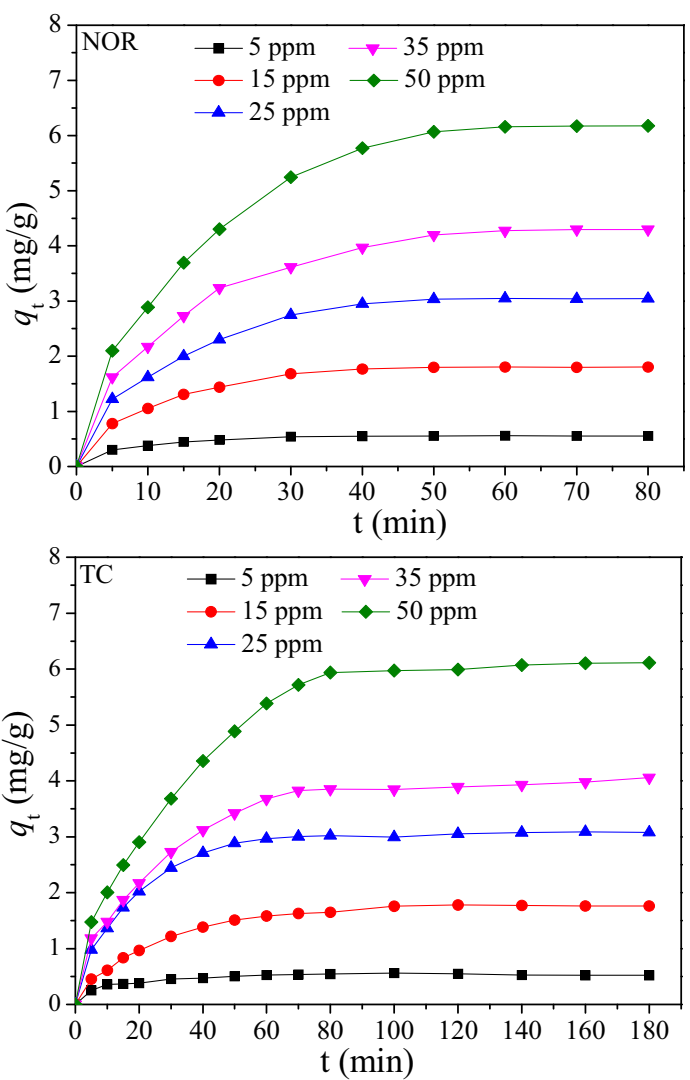
norfloxacin (NOR), metronidazole (MDE), and tetracycline (TC), were selected. Focusing on the sorption behavior of these antibiotics onto GAC, mechanism and isotherm parameters were calculated. The present research may provide a basic road to remove antibiotics through activated carbon.

\section{Materials and Methods}

\subsection{Chemicals}

Sulfadiazine (purity $>99 \%$ ), norfloxacin (purity > 98\%), metronidazole (purity $>99.5 \%$ ), and tetracycline (purity $>98 \%$ ) were all purchased from Dr. Ehrenstorfer (Germany). The chemical structures and physicochemical properties were presented in Fig. 1 Acetonitrile (purity $>99.9 \%$ ) was bought from Sigma-Aldrich (Shanghai, China). Ultrapure water was prepared by the SPI-11-10T apparatus (Sichuang, China).
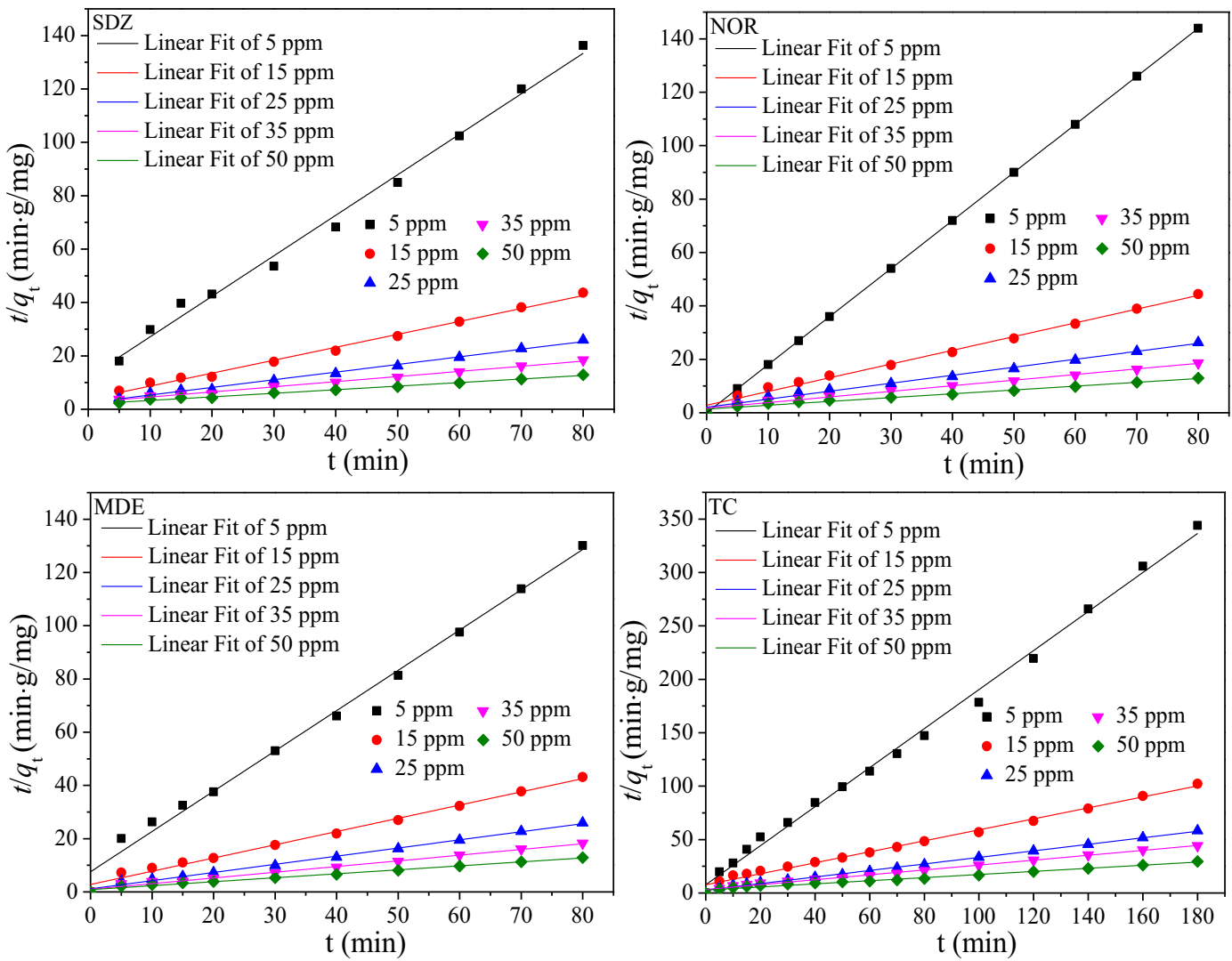

Fig. 5 Plots of the pseudo-second-order kinetics of the antibiotics on GAC at various initial concentrations 
Table 1 Parameters of the pseudo-first-order and pseudo-second-order kinetic models for the sorption of the four antibiotics onto GAC at $25^{\circ} \mathrm{C}$

\begin{tabular}{|c|c|c|c|c|c|c|c|c|c|c|c|}
\hline \multirow[t]{2}{*}{ Sorbate } & \multirow[t]{2}{*}{$C_{0}(\mathrm{mg} / \mathrm{L})$} & \multirow[t]{2}{*}{$q_{\mathrm{e}, \exp }(\mathrm{mg} / \mathrm{g})$} & \multicolumn{4}{|c|}{ Pseudo-first-order model } & \multicolumn{5}{|c|}{ Pseudo-second-order model } \\
\hline & & & $q_{\mathrm{e}, \mathrm{cal}}(\mathrm{mg} / \mathrm{g})$ & $K_{1}$ & $\Delta p(\%)$ & $R^{2}$ & $q_{\mathrm{e}, \mathrm{cal}}(\mathrm{mg} / \mathrm{g})$ & $K_{2}$ & $K_{2} q_{\mathrm{e}, \mathrm{cal}}^{2}$ & $\Delta p(\%)$ & $R^{2}$ \\
\hline \multirow[t]{5}{*}{ SDZ } & 5 & 0.588 & 0.062 & 0.003 & 29.82 & 0.446 & 0.658 & 0.193 & 0.083 & 15.61 & 0.993 \\
\hline & 15 & 1.834 & 1.988 & 0.003 & 2.850 & 0.725 & 2.062 & 0.061 & 0.259 & 4.197 & 0.993 \\
\hline & 25 & 3.083 & 5.063 & 0.004 & 21.41 & 0.832 & 3.378 & 0.033 & 0.377 & 3.193 & 0.995 \\
\hline & 35 & 4.333 & 7.599 & 0.003 & 25.13 & 0.619 & 5.181 & 0.019 & 0.510 & 6.526 & 0.995 \\
\hline & 50 & 6.200 & 15.01 & 0.004 & 47.36 & 0.594 & 7.468 & 0.011 & 0.613 & 13.83 & 0.994 \\
\hline \multirow[t]{5}{*}{ NOR } & 5 & 0.556 & 0.436 & 0.003 & 7.185 & 0.647 & 0.556 & 0.379 & 0.117 & 0.012 & 1.000 \\
\hline & 15 & 0.802 & 3.313 & 0.004 & 27.94 & 0.799 & 1.946 & 0.094 & 0.356 & 2.672 & 0.992 \\
\hline & 25 & 3.045 & 3.593 & 0.003 & 5.997 & 0.668 & 3.344 & 0.043 & 0.481 & 3.271 & 0.987 \\
\hline & 35 & 4.298 & 9.806 & 0.004 & 42.71 & 0.778 & 4.762 & 0.026 & 0.589 & 3.595 & 0.985 \\
\hline & 50 & 6.173 & 14.87 & 0.004 & 46.96 & 0.796 & 6.993 & 0.015 & 0.734 & 4.426 & 0.978 \\
\hline \multirow[t]{5}{*}{ MDE } & 5 & 0.615 & 2.273 & 0.006 & 89.86 & 0.869 & 0.661 & 0.303 & 0.132 & 2.491 & 0.993 \\
\hline & 15 & 1.858 & 1.752 & 0.003 & 1.897 & 0.646 & 2.012 & 0.088 & 0.356 & 2.768 & 0.991 \\
\hline & 25 & 3.081 & 3.959 & 0.004 & 9.501 & 0.838 & 3.268 & 0.080 & 0.854 & 2.025 & 0.994 \\
\hline & 35 & 4.375 & 2.956 & 0.003 & 1.811 & 0.833 & 4.673 & 0.048 & 1.048 & 2.271 & 0.991 \\
\hline & 50 & 6.199 & 7.980 & 0.004 & 9.579 & 0.736 & 6.711 & 0.026 & 1.171 & 2.756 & 0.991 \\
\hline \multirow[t]{5}{*}{$\mathrm{TC}$} & 5 & 0.560 & 0.166 & 0.0003 & 18.81 & 0.146 & 0.547 & 0.431 & 0.129 & 0.636 & 0.996 \\
\hline & 15 & 1.779 & 1.309 & 0.0005 & 7.071 & 0.435 & 1.945 & 0.034 & 0.130 & 2.494 & 0.992 \\
\hline & 25 & 3.087 & 2.351 & 0.0006 & 6.375 & 0.703 & 3.268 & 0.027 & 0.288 & 1.563 & 0.996 \\
\hline & 35 & 4.060 & 4.716 & 0.0005 & 4.318 & 0.578 & 4.367 & 0.016 & 0.305 & 2.020 & 0.992 \\
\hline & 50 & 6.112 & 9.207 & 0.0007 & 13.54 & 0.774 & 6.849 & 0.010 & 0.469 & 3.228 & 0.986 \\
\hline
\end{tabular}

temperature, the MDE solution was transferred into a 500-mL measuring flask. The flask was filled up to $500 \mathrm{~mL}$ with ultrapure water. The way of obtaining TC stock solution was the same as that of MDE. The final concentration of MDE and TC was $1.000 \mathrm{~g} / \mathrm{L}$. The stock solutions of SDZ and NOR were acquired by dissolving $0.400 \mathrm{~g}$ reagent into $50 \mathrm{~mL}$ acetonitrile and stirred, respectively. After dissolving, two $100-\mathrm{mL}$ measuring flasks were added with each antibiotic solution and $100 \mathrm{~mL}$ acetonitrile. Finally, the concentration of SDZ and NOR was $4.000 \mathrm{~g} / \mathrm{L}$. Testing solutions were obtained from diluting stock solutions with a known volume of ultrapure water. For the effect of temperature and solution $\mathrm{pH}(2.0-11.0)$, which ranged from 15 to $55^{\circ} \mathrm{C}$, these were adjusted by $0.1 \mathrm{~mol} / \mathrm{L} \mathrm{NaOH}$ or $0.1 \mathrm{~mol} / \mathrm{L} \mathrm{HCl}$ solution, respectively.

A series of batch tests were operated to investigate the four antibiotics' sorption performance in beakers. A mass of $0.4 \mathrm{~g} \mathrm{GAC}$ and $50 \mathrm{~mL}$ of SDZ (NOR or MDE) at neutral $\mathrm{pH}$ (7.0) were added into a beaker. A mass of
$0.6 \mathrm{~g}$ of GAC was employed for $75 \mathrm{~mL}$ of TC with neutral $\mathrm{pH}$ (7.0). All beakers were covered with parafilm and shaken on a horizontal shaker $(150 \mathrm{rpm})$ at $25^{\circ} \mathrm{C}$. A $5-\mathrm{mL}$ syringe was used to withdraw the sample at a certain time interval. Filter liquor was used for estimating the concentrations of the four antibiotics. The blanks were also operated at the same experimental conditions. All experiments were performed in triplicate and average values were calculated.

\subsection{Analysis and Methods}

The surface area and porous structure of GAC were analyzed through nitrogen sorption/desorption isotherm measured at $77 \mathrm{~K}$ using a physisorption analyzer (SSA4200). Standard curves were used for calculating the residual concentrations. The absorbance of SDZ, NOR, MDE, and TC can be detected at $264 \mathrm{~nm}$ (Yang et al. 2011), $273 \mathrm{~nm}$ (Liu et al. 2011), $320 \mathrm{~nm}$ (Çaliskan and Goktürk 2010), and 360 nm (Sayğılı and Güzel 2016) by 

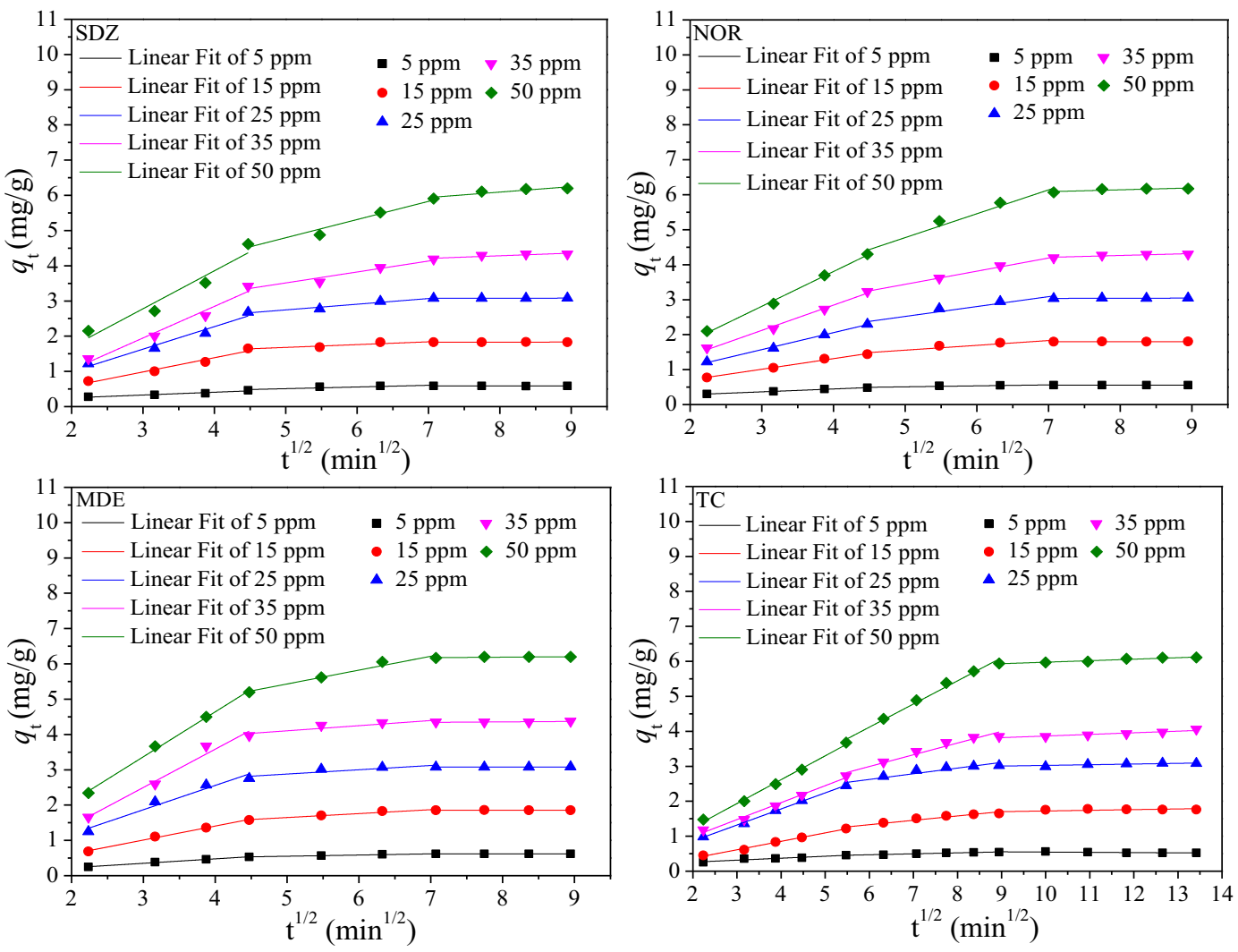

Fig. 6 Intraparticle diffusion plots of the antibiotics' sorption onto GAC

a UV-Visible spectrophotometer (TU-1810), respectively. For calculating the mass of antibiotics sorbed onto GAC, the following equation was introduced:

$q_{t}=\frac{\left(C_{0}-C\right)}{M} \times V$

where $C_{0}$ is the initial concentration of the respective antibiotics (in milligrams per liter) in the solution and $C$ is the residual solution concentration (in milligrams per liter) after sorption experiments. $V$ and $M$ are the volumes of the antibiotic solution (in liters) and the mass of GAC (in grams), respectively.

\section{Results and Discussion}

\subsection{Textural Property of Granular Activated Carbon}

As presented in Fig. 2, the GAC sample possesses a type I sorption isotherm with BET-specific surface area (SSA) of approx. $1200 \mathrm{~m}^{2} / \mathrm{g}$. The $t$-plots of the micropore surface area and external surface area were found to be 293 and $639 \mathrm{~m}^{2} / \mathrm{g}$, respectively. The total pore volume and micropore volume were 1.31 and $0.13 \mathrm{~cm}^{3} / \mathrm{g}$ $\left(P / P_{0}=0.9989\right)$, respectively, using the Barrett-JoynerHalenda method at $P / P_{0}$ of 0.9989 . Due to possessing high surface area and large pore volume, this type of GAC may be an ideal sorbent for removing antibiotics from wastewater.

\subsection{Influence of Temperature and $\mathrm{pH}$}

Figure $3 \mathrm{a}$ shows the plots of removal rate against temperature. When the temperature ranged from 15 to $55{ }^{\circ} \mathrm{C}$, the antibiotic removal rate changed slightly. Generally speaking, a lower temperature is beneficial to the sorption process. However, it seems that the sorption of these antibiotics on GAC was not affected by temperature. The plots of the removal rate versus $\mathrm{pH}(2.0-11.0)$ are presented in Fig. 3b. It can also be found that $\mathrm{pH}$ had a slight influence on the sorption. In other literature reports, for instance, the sorption of SDZ to F-400 was relatively insensitive to $\mathrm{pH}$ (Yang et al. 2011). In lotus stalk-based activated carbon for the sorption of NOR, the values of $\mathrm{pH}$ and temperature were selected as 6.5 and 
$21{ }^{\circ} \mathrm{C}$, respectively (Liu et al. 2011). For coal-based activated carbon sorption of MDE, $\mathrm{pH}$ had a slight effluence and temperature was selected as $25{ }^{\circ} \mathrm{C}$ (Queiroz et al. 2005). In activated carbon prepared from tomato (TAC, L. esculentum Mill.), the sorption process was examined at natural $\mathrm{pH}$ (5.7) of the TAC-TC system in aqueous solution, and the maximum sorption capacity of the Langmuir model was identified as $500.0 \mathrm{mg} / \mathrm{L}$ at $35{ }^{\circ} \mathrm{C}$ (Liu et al. 2011). These results showed that the removal of SDZ, NOR, MDE, and TC by GAC from aqueous solution can be operated under a wide temperature and $\mathrm{PH}$ range. For the later studies, the solution temperature was selected as $25^{\circ} \mathrm{C}$ and the $\mathrm{pH}$ of the antibiotic stocking solutions was set at 7.0.

\subsection{Determination of the Equilibrium Time}

The values of $q_{\mathrm{t}}$ were plotted against contact time in order to determine the sorption equilibrium. The results are reflected in Fig. 4. It was observed that the sorption amount of SDZ increased rapidly within $30 \mathrm{~min}$ (especially for the test solution with a higher initial SDZ concentration), and the linear gradually became smooth when time ranged from 30 to $80 \mathrm{~min}$. These curves were presented for describing the sorption of NOR and MDE with the same trend. However, the sorption of TC was slower compared to those of SDZ, NOR, and MDE. After $60 \mathrm{~min}$, the sorption amount of TC on GAC increased slightly. The concentrations of the antibiotics had no obvious decrease trend in individual controls when the shaking time was prolonged to $200 \mathrm{~min}$; thus, it can eliminate other possible processes contributing to the removal of antibiotics during the batch sorption experiments, for example, sorption to the glass walls of flasks or evaporation resulting in the decrease of SDZ, NOR, MDE, and TC. It is noted here that the equilibrium sorption time of the four antibiotics slightly increased with the increase in initial concentrations (Fig. 4). For example, when the concentration of SDZ ranged from 15 to $50 \mathrm{ppm}$, the equilibrium time correspondingly varied from 40 to $60 \mathrm{~min}$. Therefore, for SDZ, NOR, and MDE, the

Table 2 Intraparticle diffusion kinetic model parameters at $25^{\circ} \mathrm{C}$

\begin{tabular}{|c|c|c|c|c|c|c|c|c|c|c|}
\hline \multirow[t]{2}{*}{ Sorbate } & \multirow[t]{2}{*}{$C_{0}(\mathrm{mg} / \mathrm{L})$} & \multicolumn{9}{|c|}{ Intra-particle diffusion model } \\
\hline & & $K_{\mathrm{id} 1}\left(\mathrm{mg} / \mathrm{g} \cdot \min ^{1 / 2}\right)$ & $I_{1}(\mathrm{mg} / \mathrm{g})$ & $R^{2}$ & $K_{\mathrm{id} 2}\left(\mathrm{mg} / \mathrm{g} \cdot \mathrm{min}^{1 / 2}\right)$ & $I_{2}(\mathrm{mg} / \mathrm{g})$ & $R^{2}$ & $K_{\mathrm{id} 3}\left(\mathrm{mg} / \mathrm{g} \cdot \min ^{1 / 2}\right)$ & $I_{3}(\mathrm{mg} / \mathrm{g})$ & $R^{2}$ \\
\hline \multirow[t]{5}{*}{ SDZ } & 5 & 0.079 & 0.090 & 0.929 & 0.048 & 0.271 & 0.745 & -0.001 & 0.595 & 0.252 \\
\hline & 15 & 0.403 & -0.227 & 0.957 & 0.079 & 1.284 & 0.826 & 0.002 & 1.813 & 0.228 \\
\hline & 25 & 0.639 & -0.286 & 0.954 & 0.161 & 1.941 & 0.940 & 0.002 & 3.067 & 0.126 \\
\hline & 35 & 0.898 & -0.745 & 0.959 & 0.311 & 1.960 & 0.912 & 0.076 & 3.680 & 0.699 \\
\hline & 50 & 1.079 & -0.457 & 0.913 & 0.517 & 2.213 & 0.943 & 0.155 & 4.851 & 0.815 \\
\hline \multirow[t]{5}{*}{ NOR } & 5 & 0.082 & 0.119 & 0.995 & 0.028 & 0.370 & 0.741 & -0.003 & 0.557 & 0.382 \\
\hline & 15 & 0.304 & 0.099 & 0.992 & 0.136 & 0.138 & 0.843 & 0.001 & 1.792 & 0.192 \\
\hline & 25 & 0.485 & 0.117 & 0.996 & 0.283 & 1.106 & 0.900 & 0.004 & 3.006 & 0.156 \\
\hline & 35 & 0.722 & -0.045 & 0.990 & 0.376 & 1.560 & 0.996 & 0.054 & 3.833 & 0.742 \\
\hline & 50 & 0.995 & -0.173 & 0.994 & 0.683 & 1.362 & 0.953 & 0.053 & 5.715 & 0.615 \\
\hline \multirow[t]{5}{*}{ MDE } & 5 & 0.126 & -0.027 & 0.995 & 0.034 & 0.384 & 0.956 & 0.001 & 0.615 & 0.546 \\
\hline & 15 & 0.396 & -0.177 & 0.994 & 0.111 & 1.091 & 0.941 & 0.008 & 1.848 & 0.325 \\
\hline & 25 & 0.688 & -0.196 & 0.947 & 0.121 & 2.272 & 0.715 & 0.001 & 3.069 & 0.354 \\
\hline & 35 & 1.085 & -0.755 & 0.966 & 0.146 & 3.377 & 0.750 & 0.013 & 4.255 & 0.586 \\
\hline & 50 & 1.272 & -0.446 & 0.996 & 0.392 & 3.468 & 0.956 & 0.014 & 6.080 & 0.443 \\
\hline \multirow[t]{5}{*}{$\mathrm{TC}$} & 5 & 0.056 & 0.147 & 0.888 & 0.027 & 0.306 & 0.964 & -0.007 & 0.620 & 0.551 \\
\hline & 15 & 0.241 & -0.110 & 0.990 & 0.125 & 0.579 & 0.931 & 0.019 & 1.529 & 0.324 \\
\hline & 25 & 0.459 & -0.056 & 0.998 & 0.163 & 1.647 & 0.860 & 0.019 & 2.829 & 0.696 \\
\hline & 35 & 0.486 & 0.023 & 0.986 & 0.335 & 0.981 & 0.947 & 0.046 & 3.403 & 0.858 \\
\hline & 50 & 0.682 & -0.109 & 0.995 & 0.662 & 0.144 & 0.986 & 0.043 & 5.547 & 0.936 \\
\hline
\end{tabular}



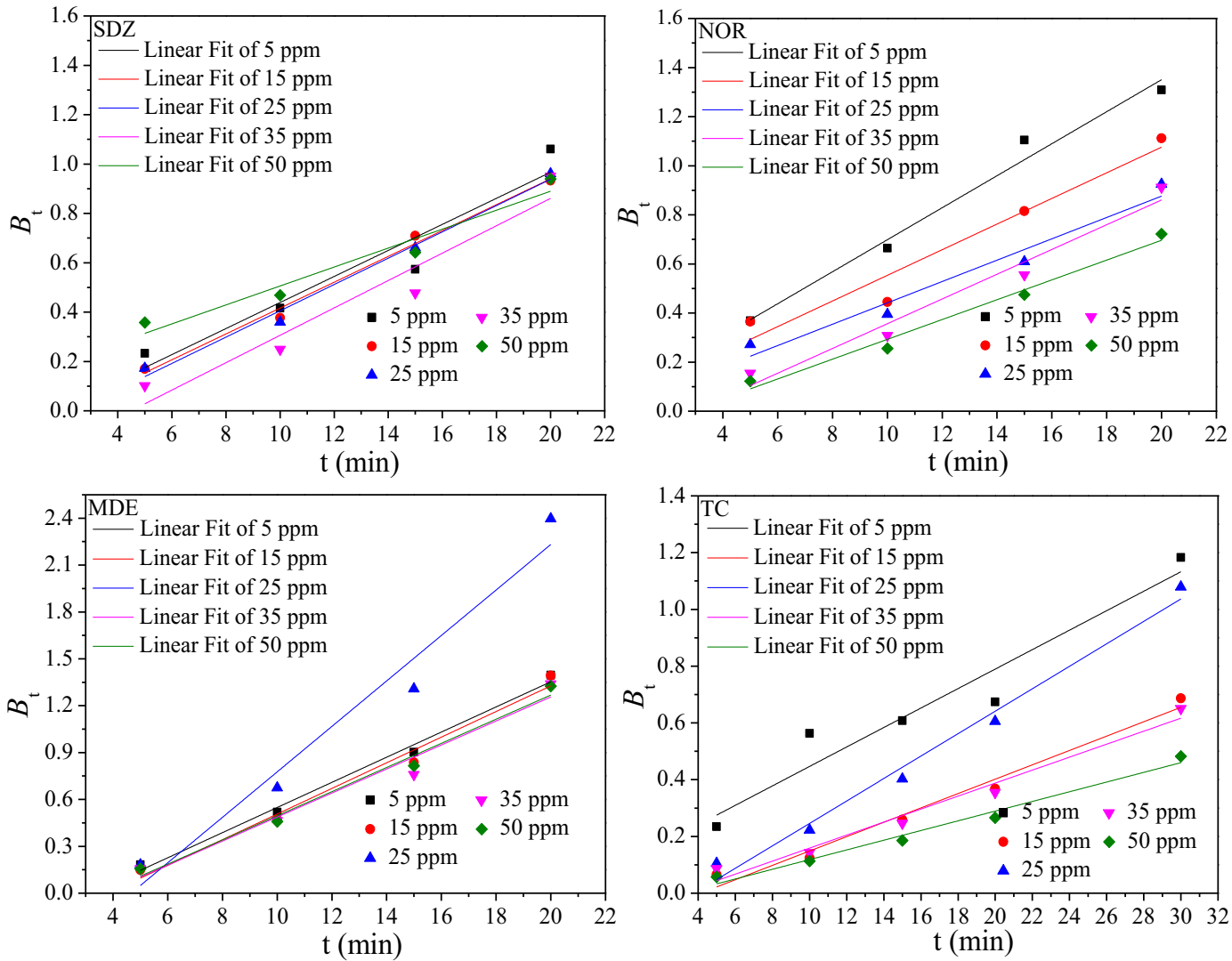

Fig. 7 Boyd plots of the antibiotics' sorption onto GAC

equilibrium time was set at 80 min while that for TC was at $180 \mathrm{~min}$.

\subsection{Sorption Kinetics}

The pseudo-first-order and pseudo-second-order models were employed to express the sorption characteristics (Lagergren and Theorieder 1898; Ho 2006) based on the following equations, respectively:

$\log \left(q_{\mathrm{e}, \exp }-q_{t}\right)=\log \left(q_{\mathrm{e}, \mathrm{cal}}\right)-K_{1} t$

$\frac{t}{q_{t}}=\frac{1}{K_{2} q_{\mathrm{e}, \mathrm{cal}}^{2}}+\frac{1}{q_{\mathrm{e}, \mathrm{cal}}} t$

where $q_{\mathrm{e}, \text { exp }}$ and $q_{t}$ (both in milligrams per gram) are the sorption amounts of antibiotics onto GAC at equilibrium and time $t$, respectively. $K_{1}$ and $K_{2}$ are the rate constants of the sorption kinetics for Eq. 2 (1/min) and Eq. 3 (g/mg.min), respectively.
In order to further verify the best-fit kinetic model of sorption, the mathematical expression of normalized standard deviation $\Delta q$ (in percent) was employed and given as (Ahmed and Theydan 2013a, b):

$\Delta q(\%)=100 \sqrt{\frac{\sum\left[\left(q_{t, \exp }-q_{t, \mathrm{cal}}\right) / q_{t, \exp }\right]^{2}}{N-1}}$

where $N$ is the number of data points and $q_{t, \text { exp }}$ and $q_{t, \text { cal }}$ (in milligrams per gram) are the measured and theoretical sorption capacities, respectively.

The first-order kinetic model was only suitable for the experimental data in the first $30 \mathrm{~min}$ (not shown). However, the $R^{2}$ values from Eq. 3 were high and close to unity in all batch sorption. It can be concluded that the sorption of SDZ, NOR, MDE, and TC on GAC was not a first-order reaction (Fig. 5). In addition, the $\Delta q$ values were low and $q_{\mathrm{e}, \mathrm{cal}}$ were close to $q_{\mathrm{e} \text {,exp }}$, which also suggested that the kinetic data were well described by the second-order kinetic model (Table 1). These results demonstrated that the sorption of the four antibiotics on GAC was a chemisorption process, involving valency 
forces through sharing or exchange of electrons between the sorbent and sorbate (Ho and Mckay 1999).

According to the values of $q_{\mathrm{e}, \text { cal }}$, it was found that the sorption capacity of GAC towards the four antibiotics followed the trend SDZ $>$ NOR $>$ MDE $>$ TC. The initial sorption rate $K_{2} q_{\mathrm{e} \text {,cal }}^{2}$ gradually increased with increasing original concentrations of sorbates (Table 1), suggesting that a high antibiotic concentration improved the driving force to overcome the mass transfer-resistant barrier between the solid and aqueous phases. Moreover, the values of $K_{2} q_{\mathrm{e}, \mathrm{cal}}{ }^{2}$ for MDE under the same original concentrations were higher than those for SDZ, NOR, and TC. This indicated that the rates of antibiotic removal by GAC followed the order MDE $>$ NOR $>$ SDZ $>$ TC (Ofomaja et al. 2010).

\subsection{Sorption Mechanism}

To investigate the rate-controlling step, the Weber and Morris intraparticle diffusion model was introduced to analyze the kinetics data (EI-Khaiary et al. 2010) and shown as follows:

$q_{t}=K_{\mathrm{id}} t^{1 / 2}+I$

where $q_{t}$ (in milligrams per gram) is the amount of sorbate sorbed at any time $t, K_{\mathrm{id}}$ is the rate constant of the model $\left(\mathrm{mg} / \mathrm{g} \cdot \min ^{1 / 2}\right)$, and $I$ (in milligrams per gram) is the intercept, related to the thickness of the boundary layer from the plots of $q_{t}$ against $t^{1 / 2}$.

It is widely acknowledged that the sorption process includes three consecutive steps (Tang et al. 2012): (1) transport of sorbate molecules from aqueous solution to the sorbent exterior surface by boundary layer diffusion; (2) intraparticle diffusion of the sorbate molecules transferred into the sorbent pores; and (3) sorption of the sorbate molecules onto the interior surfaces of the pores and capillary spaces of the sorbent. The third section of the fitted curve was relatively smooth. Figure 6 shows the plots from $q_{t}$ against $t^{1 / 2}$ for SDZ at different initial concentrations. It was found that the fitted curves of the plots can be separated into three different linear segments. The first segment presented a faster sorption rate with contact time ranging from 0 to $20 \mathrm{~min}$, the remaining two segments in the range from 20 to $50 \mathrm{~min}$ and from 50 to $80 \mathrm{~min}$, respectively. Values of the rate constant and intercept are given in Table 2. The results revealed that the diffusion trend gradually became slow, with the rate constant decreased as contact time increased. If the dominant step was controlled by intraparticle diffusion, the linear should pass through the origin $\left(I_{1}=0\right)$. For SDZ, the $I_{1}$ values of the first portion were different between -0.745 and 0.090 , which did not pass through the original point. So it is suggested that the sorption behavior of SDZ onto GAC was conducted by boundary layer and intraparticle diffusion, or boundary layer was the only rate-controlling step.

To further ascertain the real control step related to the sorption process, experimental data were calculated through the Boyd's film diffusion model, which assumed that the boundary layer surrounding the GAC is the primary resistance to diffusion (Tang et al. 2012). The relevant expression (Tang et al. 2012) was given in the following:

$F(t)=1-\left(\frac{6}{\pi^{2}}\right) \sum_{n=1}^{\infty}\left(\frac{1}{n^{2}}\right) \exp \left(-n^{2} B t\right)$

where $F(t)=q_{t} / q_{\mathrm{e}}$ is the fraction of the antibiotics sorbed at time $t$ and at equilibrium and $B_{t}$ is a function of $F(t)$. If $F(t)$ values are higher than 0.85 ,

Table 3 Boyd kinetic model parameters at $25^{\circ} \mathrm{C}$

\begin{tabular}{llll}
\hline Sorbate & $C_{0}(\mathrm{mg} / \mathrm{L})$ & \multicolumn{2}{c}{ Boyd plot } \\
\cline { 3 - 4 } & & Intercept & $R^{2}$ \\
\hline SDZ & 5 & -0.061 & 0.901 \\
& 15 & -1.078 & 0.988 \\
& 25 & -0.128 & 0.984 \\
& 35 & -0.249 & 0.898 \\
& 50 & 0.122 & 0.930 \\
NOR & 5 & 0.046 & 0.974 \\
& 15 & 0.031 & 0.924 \\
& 25 & 0.010 & 0.944 \\
& 35 & -0.148 & 0.953 \\
& 50 & -0.111 & 0.975 \\
MDE & 5 & -0.256 & 0.989 \\
& 15 & -0.314 & 0.974 \\
& 25 & -0.678 & 0.949 \\
& 35 & -0.281 & 0.955 \\
& 50 & -0.278 & 0.978 \\
TC & 5 & 0.104 & 0.911 \\
& 15 & -0.104 & 0.973 \\
& 25 & -0.150 & 0.981 \\
& 35 & -0.070 & 0.966 \\
& 50 & -0.052 & 0.976 \\
\hline
\end{tabular}



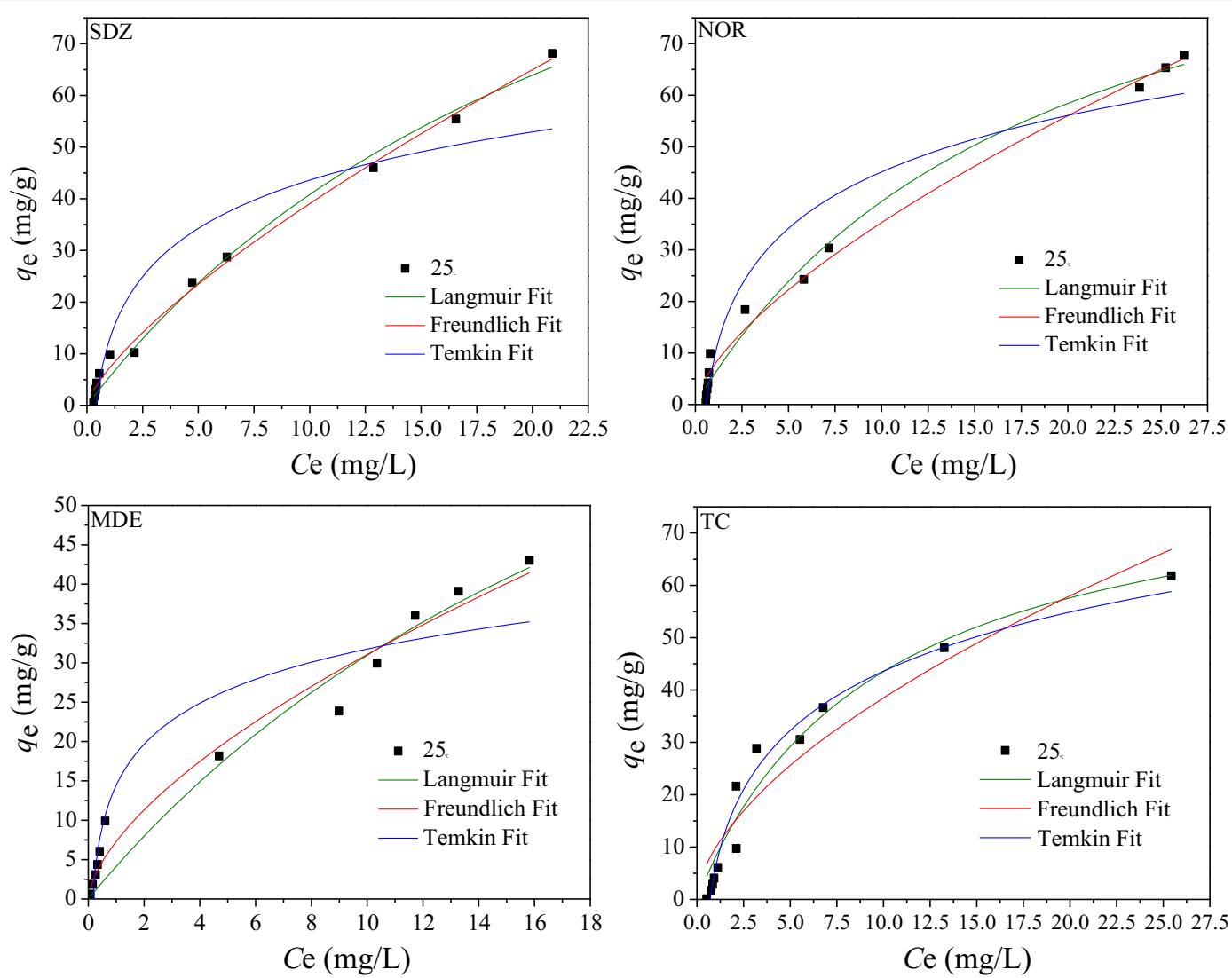

Fig. 8 Sorption isotherms of the antibiotics onto GAC

$B_{t}=0.4977-\ln (1-F(t))$

If $F(t)$ values are lower than 0.85 ,

$B_{t}=\left(\sqrt{\pi}-\sqrt{\pi-\left(\frac{\pi^{2} F(t)}{3}\right)}\right)^{2}$

From the Boyd's film diffusion model, if the plots of $B_{t}$ versus $t$ are linear and pass through the origin, it can be concluded that intraparticle diffusion is the main rate- controlling step in the process of mass transfer (Tang et al. 2012). If the plot is nonlinear or linear but does not pass through the origin, then sorption rate is controlled by film diffusion or chemical reaction (Tang et al. 2012). Figure 7 presents the fitted curves of the Boyd's model for the sorption of SDZ on GAC in the first $20 \mathrm{~min}$. The results of the calculated parameters can be seen in Table 3. It was found that the intercepts of all plots ranged from -1.078 to 0.122 , which were far away from the origin. This concludes that the sorption rate of SDZ on GAC from 0 to $20 \mathrm{~min}$ was controlled by film

Table 4 Parameters of the isotherm models describing the sorption of antibiotics on GAC at $25^{\circ} \mathrm{C}$

\begin{tabular}{|c|c|c|c|c|c|c|c|c|c|}
\hline \multirow[t]{2}{*}{ Sorbate } & \multicolumn{3}{|c|}{ Temkin } & \multicolumn{3}{|l|}{ Langmuir } & \multicolumn{3}{|l|}{ Freundlich } \\
\hline & $B$ & $K_{\mathrm{T}}$ & $R^{2}$ & $q_{\mathrm{m}}(\mathrm{mg} / \mathrm{g})$ & $K_{\mathrm{L}}(\mathrm{L} / \mathrm{mg})$ & $R^{2}$ & $K_{\mathrm{F}}\left(\mathrm{mg} / \mathrm{L}^{(1-1 / n)} \cdot \mathrm{g}\right)$ & $n$ & $R^{2}$ \\
\hline SDZ & 13.47 & 2.545 & 0.883 & 147.12 & 0.038 & 0.998 & 7.197 & 1.361 & 0.995 \\
\hline NOR & 15.78 & 1.748 & 0.940 & 112.86 & 0.054 & 0.989 & 7.618 & 1.501 & 0.989 \\
\hline MDE & 7.524 & 6.809 & 0.899 & 110.64 & 0.039 & 0.985 & 7.313 & 1.592 & 0.974 \\
\hline $\mathrm{TC}$ & 16.30 & 1.450 & 0.965 & 85.29 & 0.104 & 0.950 & 9.886 & 1.693 & 0.950 \\
\hline
\end{tabular}


Table 5 Comparison of the antibiotics' sorption capacity over various absorbents

\begin{tabular}{|c|c|c|c|c|c|c|c|c|}
\hline Sorbate & Absorbents & $S_{\mathrm{BET}}\left(\mathrm{m}^{2} / \mathrm{g}\right)$ & $T(\mathrm{~h})$ & Dose $(\mathrm{g} / \mathrm{L})$ & $\mathrm{pH}$ & $T\left({ }^{\circ} \mathrm{C}\right)$ & $q_{\mathrm{m}}(\mathrm{mg} / \mathrm{g})$ & References \\
\hline \multirow[t]{2}{*}{ SDZ } & Granular activated carbon & 1200 & 1.3 & 8.00 & 7.0 & 25 & 147.1 & This work \\
\hline & Molecularly imprinted polymers & - & 2.0 & 1.42 & 7.0 & 25 & 7.098 & Ma et al. (2015) \\
\hline \multirow[t]{4}{*}{ NOR } & Granular activated carbon & 1200 & 1.3 & 8.00 & 7.0 & 25 & 112.8 & This work \\
\hline & Carboxylated multiwall carbon nanotube & 160.0 & 30 & 0.50 & 7.0 & 30 & 88.50 & Yang et al. (2012) \\
\hline & $\begin{array}{l}\text { Iron-doped activated alumina } \\
\qquad\left(\mathrm{Al}_{2} \mathrm{O}_{3} / \mathrm{Fe}\right)\end{array}$ & 140.6 & 16 & 3.00 & 6.5 & 21 & 32.55 & Liu et al. (2011) \\
\hline & Fe-MCM-41 molecular sieves & 984.2 & 0.5 & 0.05 & 7.0 & 25 & 102.9 & Chen et al. (2015) \\
\hline \multirow[t]{4}{*}{ MDE } & Granular activated carbon & 1200 & 1.3 & 8.00 & 7.0 & 25 & 110.6 & This work \\
\hline & Multiwall carbon nanotube & 144.0 & 24 & - & 7.0 & 25 & 49.80 & $\begin{array}{l}\text { Carrales-Alvarado } \\
\text { et al. (2014) }\end{array}$ \\
\hline & Hydroxyapatite & - & 7.0 & 100 & 7.0 & 25 & 0.000 & Queiroz et al. (2005) \\
\hline & $\begin{array}{l}\text { Almond shells activated } \\
\text { carbon (ACA1) }\end{array}$ & 103.7 & 2.0 & 1.00 & 7.0 & 25 & 64.98 & $\begin{array}{l}\text { Flores-Cano } \\
\text { et al. (2016) }\end{array}$ \\
\hline \multirow[t]{4}{*}{$\mathrm{TC}$} & Granular activated carbon & 1200 & 3.0 & 8.00 & 7.0 & 25 & 85.29 & This work \\
\hline & Alkali biochar & 117.8 & 60 & 5.00 & 7.0 & 30 & 58.82 & Liu et al. (2012) \\
\hline & Diatomite & - & 2.0 & 5.00 & 7.0 & 45 & 34.00 & Chao et al. (2014) \\
\hline & Bamboo charcoal & 67.80 & 24 & 1.00 & 7.0 & 30 & 22.70 & Liao et al. (2013) \\
\hline
\end{tabular}

diffusion; that is to say, the boundary layer was the dominant step for diffusion in all batch sorption processes. It is noted here that the same conclusion was also suitable for the sorption mechanisms of NOR, SDE, and TC on GAC.

\subsection{Sorption Isotherm}

The performance of the sorption process depends not only on the rate at which mass transfer occurs but also on the sorbent-sorbate equilibrium concentration (Mannarswamy et al. 2009). Three twoparameter isotherm models, called the Temkin (Ahmed and Theydan 2013a, b), Langmuir (Langmuir 1918), and Freundlich (Freundlich 1906), were employed. The respective mathematical expressions of these isotherm models were represented as follows:

$q_{\mathrm{e}}=B \ln \left(K_{\mathrm{T}} C_{\mathrm{e}}\right)$

$q_{\mathrm{e}}=\frac{q_{\mathrm{m}} K_{\mathrm{L}} C_{\mathrm{e}}}{1+K_{\mathrm{L}} C_{\mathrm{e}}}$

$q_{\mathrm{e}}=K_{\mathrm{F}} C_{\mathrm{e}}^{1 / \mathrm{n}}$

where $B$ is the Temkin constant of the sorption heat and $K_{\mathrm{T}}(1 / \mathrm{mg})$ is the Temkin isotherm constant. $C_{\mathrm{e}}$ is the residual concentration of the sorbate at equilibrium (in milligrams per liter), $q_{\mathrm{e}}$ is the amount of sorbate per unit mass of sorbent (in milligrams per gram), and $q_{\mathrm{m}}$ is the maximum sorption capacity (in milligrams per gram). $K_{\mathrm{L}}$ is the Langmuir constant (in liters per milligram) and $K_{\mathrm{F}}\left(\mathrm{mg} / \mathrm{L}^{(1-1 / n)} \cdot \mathrm{g}\right)$ and $n$ are constants of the Freundlich model, which respectively stand for sorption capacity and intensity.

The parameters, along with the correlation coefficients $R^{2}$ and constants, were calculated by the plots of $C_{\mathrm{e}}$ against $q_{\mathrm{e}}$ with non-linear forms using Origin 8.5 software (Fig. 8). As shown in Table 4, the best-fitting model was Langmuir for the isotherm data. The applicability of the Langmuir model indicated the monolayer coverage of the antibiotics on the surface of GAC. For $q_{\mathrm{m}}$ values, it is suggested that the maximum sorption capacity of the four antibiotics followed the trend SDZ $>$ NOR $>$ MDE $>$ TC. Table 5 summarizes the sorption capacity of several sorbents towards antibiotics SDZ, NOR, MDE, and TC. It can be seen that GAC is a

Table 6 Values of the separation factor $R_{\mathrm{L}}$

\begin{tabular}{lll}
\hline Sorbate & $C_{0}(\mathrm{mg} / \mathrm{L})$ & $R_{\mathrm{L}}$ \\
\hline SDZ & 25 & 0.513 \\
NOR & 25 & 0.426 \\
MDE & 25 & 0.506 \\
TC & 25 & 0.278 \\
\hline
\end{tabular}


very powerful and effective sorbent for removing these antibiotics from contaminated water. For example, the maximum sorption capacity of GAC towards NOR was $112.8 \mathrm{mg} / \mathrm{g}$, which was higher than that of carboxylated multiwall carbon nanotube, $\mathrm{Al}_{2} \mathrm{O}_{3} / \mathrm{Fe}$ and Fe-MCM-41 molecular sieves.

The variable $K_{\mathrm{L}}$ is related to the binding energy (Zhang et al. 2014). If the value of $K_{\mathrm{L}}$ is larger, then the degree of spontaneous reactions is more likely. Therefore, the sorption intensity of SDZ was higher than those of NOR, MDE, and TC. The constant $n$ values for these antibiotics were greater than 1 unit, indicating the favorability of the process of sorption (Ahmed and Theydan 2013a, b). The values of separation factor $R_{\mathrm{L}}$ further confirmed the favorable sorption process (Table 6). The essential feature of the Langmuir isotherm can be expressed in terms of the separation factor $R_{\mathrm{L}}$ (Sheela and Nayaka 2012).

$$
R_{\mathrm{L}}=\frac{1}{\left(1+K_{\mathrm{L}} C_{0}\right)}
$$

where $R_{\mathrm{L}}$ is a dimensionless constant. $R_{\mathrm{L}}>1.0$ indicates unfavorable sorption, $0<R_{\mathrm{L}}<1.0$ favorable sorption, $R_{\mathrm{L}}=1.0$ linear sorption, and $R_{\mathrm{L}}=0$ indicates irreversible sorption.

\section{Summary}

This work discussed the experiment of granular activated carbon (GAC) obtained from rice straw for the sorption of four antibiotics, including sulfadiazine, norfloxacin, metronidazole, and tetracycline, from aqueous solution. The results showed that GAC possessed very high specific surface area and large pore volume, suggesting that it is a desirable porous sorbent for antibiotic removal. The equilibrium sorption data of sulfadiazine, norfloxacin, metronidazole, and tetracycline on GAC well agreed with the Langmuir isotherm model. The $q_{\mathrm{m}}$ values for sulfadiazine, norfloxacin, metronidazole, and tetracycline were $147.12,112.86,110.64$, and $85.29 \mathrm{mg} / \mathrm{g}$, respectively. The sorption mechanism of the four antibiotics onto GAC was explained by both the WeberMorris intraparticle diffusion and Boyd kinetic models. The results showed that the dominant step in the sorption process was the boundary layer diffusion. Temperature and $\mathrm{pH}$ exerted a weak influence on the sorption process, which means that the removal of sulfadiazine, norfloxacin, metronidazole, and tetracycline by GAC from water can be operated under a wide $\mathrm{pH}$ and temperature range.

Acknowledgements This work was funded by the National Key Research and Development Program (2016YFC0204201), National Natural Science Foundation of China (21307097, 21677114), and Fundamental Research Funds for the Central Universities (xjj2016046). We also thank the editor and anonymous reviewers for their valuable opinions.

\section{Compliance with Ethical Standards}

Conflict of Interest The authors declare that that they have no conflict of interest.

\section{References}

Adams, C., Wang, Y., Loftin, K., \& Meyer, M. (2002). Removal of antibiotics from surface and distilled water in conventional water treatment processes. Journal of Environmental Engineering, 128(3), 253-260.

Ahmed, M. J., \& Theydan, S. K. (2013a). Microporous activated carbon from Siris seed pods by microwave-induced $\mathrm{KOH}$ activation for metronidazole adsorption. Journal of Analytical and Applied Pyrolysis, 99, 101-109.

Ahmed, M. J., \& Theydan, S. K. (2013b). Microwave assisted preparation of microporous activated carbon from Siris seed pods for adsorption of metronidazole antibiotic. Chemical Engineering Journal, 214, 310-318.

Ahmed, M. B., Zhou, J. L., Ngo, H. H., \& Guo, W. S. (2015). Adsorptive removal of antibiotics from water and wastewater: progress and challenges. Science of the Total Environment, 532, 112-126.

Çaliskan, E., \& Goktürk, S. (2010). Adsorption characteristics of sulfamethoxazole and metronidazole on activated carbon. Separation Science and Technology, 45, 244-255.

Carrales-Alvarado, D. H., Ocampo-Pérez, R., Leyva-Ramos, R., \& Rivera-Utrilla, J. (2014). Removal of the antibiotic metronidazole by adsorption on various carbon materials from aqueous phase. Journal of Colloid and Interface Science, 436, 276-285.

Carstens, K. L., Gross, A. D., Moorman, T. B., \& Coats, J. R. (2013). Sorption and photodegradation processes govern distribution and fate of sulfamethazine in freshwater-sediment microcosms. Environmental Science Technology, 47, 1087710883.

Chao, Y. H., Zhu, W. S., Chen, F., Wang, P., Da, Z. L., Wu, X. Y., Ji, H. Y., Yan, S., \& Li, H. M. (2014). Commercial diatomite for adsorption of tetracycline antibiotic from aqueous solution. Separation Science and Technology, 49, 2221-2227.

Chee-Sanford, J. C., Mackie, R. I., Koike, S., Lin, I. G., Krapac, Y. F., Yannarell, A. C., Maxwell, S., \& Aminov, R. I. (2009). Fate and transport of antibiotic residues and antibiotic resistance genes following land application of manure waste. Journal of Environmental Quality, 38, 1086-1108. 
Chen, F., Ying, G. G., Kong, L. X., Wang, L., Zhao, J. L., Zhou, L. J., \& Zhang, L. J. (2011). Distribution and accumulation of endocrine disrupting chemicals and pharmaceuticals in wastewater irrigated soils in Hebei, China. Environmental Pollution, 159, 1490-1498.

Chen, D., Deng, J., Liang, J., Xie, J., Huang, K. H., \& Hu, C. H. (2013). Core-shell magnetic nanoparticles with surfaceimprinted polymer coating as a new adsorbent for solid phase extraction of metronidazole. Analytical Methods, 5, 722-728.

Chen, W. R., Li, X. K., Pan, Z. Q., Bao, Y. X., Ma, S. S., \& Li, L. S. (2015). Efficient adsorption of norfloxacin by Fe-MCM41 molecular sieves: kinetic, isotherm and thermodynamic studies. Chemical Engineering Journal, 281, 397-403.

Dabrowski, A. (2001). Adsorption-from theory to practice. Advances in Colloid and Interface Science, 93, 135-224.

Daughton, C. G., \& Ternes, T. A. (1999). Pharmaceuticals and personal care products in the environment: agents of subtle change? Environmental Health Perspectives, 07, 907-938.

EI-Khaiary, M. I., Malash, G. F., \& Ho, Y. (2010). On the use of linearized pseudo-second-order kinetic equations for modeling adsorption systems. Desalination, 257, 93-101.

Flores-Cano, J. V., Sanchez-Polo, M., Messoud, J., Velo-Gala, I., Ocampo-Perez, R., \& Rivera-Utrilla, J. (2016). Overall adsorption rate of metronidazole, dimetridazole and diatrizoate on activated carbons prepared from coffee residues and almond shells. Journal of Environmental Management, 169, 116-125.

Freundlich, H. (1906). Ueber die adsorption in Loesungen. Journal of Physical Chemistry, 57, 385-470.

Golet, E. M., Alder, A. C., \& Giger, W. (2002). Environmental exposure and risk assessment of fluoroquinolone antibacterial agents in wastewater and river water of the Glatt Valley Watershed, Switzerland. Environmental Science Technology, $36,3645-3651$.

Gómez-Pacheco, C. V., Sánchez-Polo, M., Rivera-Utrilla, J., \& López-Peñalver, J. (2011). Tetracycline removal from waters by integrated technologies based on ozonation and biodegradation. Chemical Engineering Journal, 178, 115-121.

He, J. S., Dai, J. D., Zhang, T., Sun, J., Xie, A. T., Tian, S. J., Yan, Y. S., \& Huo, P. W. (2016). Preparation of highly porous carbon from sustainable $\alpha$-cellulose for superior removal performance of tetracycline and sulfamethazine from water. Royal Society of Chemistry, 6, 28023-28033.

Ho, Y. S. (2006). Review of second-order models for adsorption systems. Journal of Hazardous Materials, B 136, 681-689.

Ho, Y. S., \& Mckay, G. (1999). Pseudo-second order model for sorption processes. Process Biochemistry, 34, 451-465.

Hu, X. G., Zhou, Q. X., \& Luo, Y. (2010). Occurrence and source analysis of typical veterinary antibiotics in manure, soil, vegetables and groundwater from organic vegetable bases, northern China. Environmental Pollution, 158, 2992-2998.

Kim, S., Shon, H., \& Ngo, H. H. (2010). Adsorption characteristics of antibiotics trimethoprim on powdered and granular activated carbon. Journal of Industrial and Engineering Chemistry, 16(3), 344-349.

Lagergren, S., \& Theorieder, Z. (1898). Sogenannten adsorption geloster stoffe. K Sven Vetenskaps akad Handl, 24, 1-34.

Lam, A., Rivera, A., \& Rodrídguez-Fuentes, G. (2001). Theoretical study of metronidazole adsorption on clinoptilolite. Microporous and Mesoporous Materials, 49, $157-162$.
Langmuir, I. (1918). The adsorption of gases on plane surfaces of glass, mica and platinum. Journal of American Chemical Society, 40, 1361-1403.

Liao, P., Zhan, Z., Dai, J., Wu, X., Zhang, W., Wang, K., \& Yuan, S. (2013). Adsorption of tetracycline and chloramphenicol in aqueous solutions by bamboo charcoal: a batch and fixed-bed column study. Chemical Engineering Journal, 228, 496-505.

Liu, W. F., Zhang, J., Zhang, C. L., \& Ren, L. (2011). Sorption of norfloxacin by lotus stalk-based activated carbon and irondoped activated alumina: mechanisms, isotherms and kinetics. Chemical Engineering Journal, 171, 431-438.

Liu, P., Liu, W., Jiang, H., Chen, J., Li, W., \& Yu, H. (2012). Modification of bio-char derived from fast pyrolysis of biomass and its application in removal of tetracycline from aqueous solution. Bioresource Technology, 12, 235-240.

Luo, Y., Xu, L., Rysz, M., Wang, Y. Q., Zhang, H., \& Alvarez, P. J. J. (2011). Occurrence and transport of tetracycline, sulfonamide, quinolone, and macrolide antibiotics in the Haihe River Basin, China. Environmental Science Technology, 45, $1827-1833$.

Ma, P. F., Zhou, Z. P., Yang, W. M., Tang, B. Q., Liu, H., Xu, W. Z., \& Huang, W. H. (2015). Preparation and application of sulfadiazine surface molecularly imprinted polymers with temperature-responsive properties. Journal of Applied Polymer Science, 132, 1-12.

Mannarswamy, A., Munson-McGee, S. H., Steiner, R., \& Andersen, P. K. (2009). D-optimal experimental designs for Freundlich and Langmuir adsorption isotherms. Chemometrics and Intelligent Laboratory Systems, 97, 146-151.

Martins, A. C., Pezoti, O., Cazetta, A. L., Bedin, K. C., YamazakiDiego, A. S., Bandoch-Gisele, F. G., Asefa, T., Visentainer, J. V., \& Almeida, V. C. (2015). Removal of tetracycline by $\mathrm{NaOH}$-activated carbon produced from macadamia nut shells: kinetic and equilibrium studies. Chemical Engineering Journal, 260, 291-299.

Méndez-Díaz, J., Prados-Joya, G., Rivera-Utrilla, J., LeyvaRamos, R., Sánchez-Polo, M., Ferro-García, M., \& Medellín-Castillo, N. (2010). Kinetic study of the adsorption of nitroimidazole antibiotics on activated carbons in aqueous phase. Journal of Colloid and Interface Science, 345(2), 481-490.

Ahmed, M. J., \& Theydan, S. K. (2014). Fluoroquinolones antibiotics adsorption onto microporous activated carbon from lignocellulosic biomass by microwave pyrolysis. Journal of the Taiwan Institute of Chemical Engineers, 45, 219-226.

Ocampo-Pérez, R., Orellana-Garcia, F., Sánchez-Polo, M., RiveraUtrilla, J., Velo-Gala, I., Lòpez-Ramòn, M. V., \& AlvarezMerino, M. A. (2013). Nitroimidazoles adsorption on activated carbon cloth from aqueous solution. Journal of Hazardous Materials, 401, 116-124.

Ofomaja, A. E., Naidoo, E. B., \& Modise, S. J. (2010). Dynamic studies and pseudo-second order mode ling of copper(II) biosorption onto pine cone powder. Desalination, 251, 112-122.

Pouretedal, H., \& Sadegh, N. (2014). Effective removal of amoxicillin, cephalexin, tetracycline and penicillin $\mathrm{G}$ from aqueous solutions using activated carbon nanoparticles prepared from vine wood. Journal of Water Process Engineering, 1, 64-73.

Queiroz, A. C., Santos, J. D., \& Monteiro, F. J. (2005). Development of a system to adsorb drugs onto calcium 
phosphate materials. Journal of Materials Science-Materials in Medicine, 16, 641-646.

Rabolle, M., \& Spliid, N. H. (2000). Sorption and mobility of metronidazole, olaquindox, oxytetracycline and tylosin in soil. Chemosphere, 40, 715-722.

Rivera-Utrilla, J., Prados-Joya, G., Sánchez-Polo, M., FerroGarcía, M. A., \& Bautista-Toledo, I. (2009). Removal of nitroimidazole antibiotics from aqueous solution by adsorption/bioadsorption on activated carbon. Journal of Hazardous Materials, 170(1), 298-305.

Sayğılı, H., \& Güzel, F. (2016). Effective removal of tetracycline from aqueous solution using activated carbon prepared from tomato (Lycopersicon esculentum Mill.) industrial processing waste. Ecotoxicology and Environmental Safety, 131, 22-29.

Sheela, T., \& Nayaka, Y. A. (2012). Kinetics and thermodynamics of cadmium and lead ions adsorption on $\mathrm{NiO}$ nanoparticles. Chemical Engineering Journal, 191, 123-131.

Tang, B., Lin, Y. W., Yu, P., \& Luo, Y. B. (2012). Study of aniline/ $\varepsilon$-caprolactam mixture adsorption from aqueous solution onto granular activated carbon: kinetics and equilibrium. Chemical Engineering Journal, 187, 69-78.

Watanabe, N., Bergamaschi, B. A., Loftin, K. A., Meyer, M. T., \& Harter, T. (2010). Use and environmental occurrence of antibiotics in freestall dairy farms with manured forage fields. Environmental Science Technology, 44, 6591-6600.

Watkinson, A. J., Murby, E. J., \& Costanzo, S. D. (2007). Removal of antibiotics in conventional and advanced wastewater treatment: implications for environmental discharge and wastewater recycling. Water Research, 41, 4164-4176.

Yahiaoui, I., Aissani-Benissad, F., Fourcade, F., \& Amrane, A. (2013). Removal of tetracycline hydrochloride from water based on direct anodic oxidation $\left(\mathrm{Pb} / \mathrm{PbO}_{2}\right.$ electrode) coupled to activated sludge culture. Chemical Engineering Journal, 221, 418-425.

Yang, W. B., Zheng, F. F., Xue, X. X., \& Lu, Y. P. (2011). Investigation into adsorption mechanisms of sulfonamides onto porous adsorbents. Journal of Colloid and Interface Science, 362, 503-509.

Yang, W. B., Lu, Y. P., Zheng, F. F., Xue, X. X., Li, N., \& Liu, D. M. (2012). Adsorption behavior and mechanisms of norfloxacin onto porous resins and carbon nanotube. Chemical Engineering Journal, 179, 112-118.

Zhang, M. M., Wang, R. Q., Guo, W., Xue, T., \& Dai, J. L. (2014). Mercury(II) adsorption on three contrasting Chinese soils treated with two source of dissolved organic matter: I. Langmuir and Freundlich isotherm evaluation. Soil \& Sediment Contamination, 23, 49-62.

Zhang, Q. Q., Ying, G. G., Pan, C. G., Liu, Y. S., \& Zhao, J. L. (2015). Comprehensive evaluation of antibiotics emission and fate in the river basins of China: source analysis, multimedia modeling, and linkage to bacterial resistance. Environmental Science Technology, 49, 6772-6782.

Zhou, L. J., Ying, G. G., Liu, S., Zhao, J. L., Yang, B., Chen, Z. F., \& Lai, H. J. (2013). Occurrence and fate of eleven classes of antibiotics in two typical wastewater treatment plants in South China. Science of the Total Environment, 452, 365-376.

Zhu, X. D., Wang, Y. J., Sun, R. J., \& Zhou, D. M. (2013a). Photocatalytic degradation of tetracycline in aqueous solution by nanosized $\mathrm{TiO}_{2}$. Chemosphere, 92, 925-932.

Zhu, Y. G., Johnson, T. A., Su, J. Q., Qiao, M., Guo, G. X., Stedtfeld, R. D., Hashsham, S. A., \& Tiedje, J. M. (2013b). Diverse and abundant antibiotic resistance genes in Chinese swine farms. Proceedings of the National Academy of Sciences of the United States of America, 110, 3435-3440. 